\title{
Frozen Soursop Puree
}

\author{
F. Sánchez Nieva, I. Hernández, L. M. Iguina de George ${ }^{1}$
}

\section{INTRODUCTION}

Soursop (Annona muricata, L.) is a tropical fruit with pleasing flavor and aroma frequently used in preparation of nectars, drinks, sherbets, ice creams, and syrups. The pulp is canned, bottled, or frozen in Puerto Rico for remanufacturing purposes, mostly for the preparation of nectars and syrups.

The pulp can be heat processed without losing much of its pleasing flavor but freezing preservation results in a higher-quality product. Frozen pulp may be manufactured into nectars and other drinks; also a frozen nectar base can be prepared for direct consumer use.

The studies reported herein were conducted to determine the effect of different variables such as heat treatment, levels of added sugar, and ascorbic acid on the quality and shelf life of frozen soursop puree.

\section{REVIEW OF LITERATURE}

Methods for preparing soursop nectar were described by Sánchez et al. (24) ${ }^{2}$ and later by Franco and Alvarez (7). Adriano et al. (1) reported on the freezing preservation of several Philippine fruits. Mathur et al. (16) studied the storage of frozen litchi, mangoes, jackfruit, and pineapples. Mustard and Stahl $(18,19)$ studied the freezing of avocados, mangoes, bananas, guavas, and pineapples. Freezing of guavas as pulp or puree, nectar base, and other products was discussed by Crues et al. (5), Orr (20), Boyle (3, 4), Lynch et al. (15), and Weight (28). Scott (25) reported on a study of the market potential for a frozen guava nectar base.

Methods for preparing frozen fruit purees were described by Joslyn and Hohl (12) and reviewed by Tressler and Evers (27). Hohl et al. (9) prepared peach purees by steaming the fruit for 4 minutes and found that heat treatment prevents oxidative changes during storage. Blanching of apples and pears resulted in a better retention of ascorbic acid. The use of ascorbic acid as an antioxidant in frozen-pack fruit was studied by Strachan and

1 Technical Director, Assistant Chemical Engineer, and Assistant Food Technologist, respectively, Food Technology Laboratory, Agricultural Experiment Station, Mayagüez Campus, University of Puerto Rico, Río Piedras, P.R. The authors wish to express their appreciation and gratitude to the members of the staff of the Food Technology Laboratory, who assisted in the chemical analyses or the flavor evaluation. Special recognition is given to D. Alcalk, Associate Bacteriologist, for conducting the microbiological analyses.

2 Italic numbers in parentheses refer to Literature Cited, pp. 235-6. 
Moyles (26). The addition of 150 to $200 \mathrm{mg}$. of ascorbic acid per 16 ounces of finished product was found adequate to protect it from oxidative changes.

The relation of ascorbic acid to color was discussed by DuBois (6). The addition of 0.02 percent ascorbic acid preserved the color of vegetables and fruit purees effectively. The addition of ascorbic acid to the fruit as it passes the finisher was found very effective. Huggart et al. (10) found the retention of ascorbic acid in frozen citrus concentrates to be approximately 98 percent in 12 months when stored at $-8^{\circ} \mathrm{F}$. Ascorbic acid retention was found to decrease with increasing temperature. Guadagni et al. (8) related ascorbic acid retention in frozen peaches to storage temperature.

Paul (21) in experiments keyed to the household production of peach, pear, plum, tomato, and other fruit purees found a better retention of color and flavor when sugar was added. Ascorbic acid retention values in excess of 100 percent were observed in some of the packs and thought to be due to the formation of reducing substances which interfered in the ascorbic acid determination. Latimer (14) recommended chilling the fruit before pulping to protect quality. Joslyn et al. (12) found that flavor and color of pulped fruit can be preserved better and oxidative deterioration minimized by deaeration. Rahman et al. (22) found the destruction of vitamin $\mathrm{C}$ in some tropical juices and nectars to be influenced by the concentration of the vitamin and sugar. A higher sugar concentration favored ascorbic acid retention.

\section{MATERIALS AND METHODS}

Commercial grade fruit was purchased directly from farmers and stored at room temperature $\left(85^{\circ} \mathrm{F}\right.$.) until ripe. The ripe fruit was sorted to discard fungus-infected fruit, washed in 20 to 40 p.p.m. free chlorine solution and rinsed with tap water.

The fruit was peeled by hand. The pulp was separated from the seeds by pulping the peeled fruit in a Langsenkamp $\mathrm{E}-\mathrm{Z}^{3}$ pulper provided with four brushes and a 0.060 - or 0.045 -inch screen as indicated in table 1 . The pulp was treated in a Langsenkamp laboratory pulper and finisher through a 0.020 -inch screen, the finisher operating at 1,600 r.p.m.

In an experiment to investigate the effect of adding ascorbic acid on the quality and shelf life of the frozen pulp, four levels of ascorbic acid (0.5, $0.75,1.00$ and $1.5 \mathrm{~g}$. per pound of pulp) were added immediately after pulping and before the finishing operation.

When sugar was used, the required quantity was dissolved by stirring and added to the pulp after finishing. Two levels were tested: $45^{\circ}$ and $59^{\circ}$ Brix.

Mention of trade names in this report does not imply recommendation or endorsement of equipment. Trade names are mentioned for the sole purpose of identifying the type of equipment used in the research. 
In the experiments to determine the effect of different heat-treatments on product quality and shelf life, the pulp from the finisher, with or without sugar or ascorbic acid, was heated to temperatures ranging from $130^{\circ}$ to $200^{\circ} \mathrm{F}$. in a laboratory Votator. After being heated, the pulp was immediately cooled to approximately $100^{\circ} \mathrm{F}$. in a second water-cooled laboratory Votator. The pulp then was chilled to about $50^{\circ} \mathrm{F}$. in a third Votator cooled with ammonia. The chilled pulp was filled into plain tin cans $211 \times 304$. The closed cans were kept in a tank with water at $45^{\circ} \mathrm{F}$. until the lot being processed was ready for freezing. All cans were quick frozen in a plate freezer at $-45^{\circ} \mathrm{F}$. and stored at $-10^{\circ} \mathrm{F}$. for the duration of the storage period.

The frozen pulps were analyzed for $\mathrm{pH}$ and total acidity, soluble and

TABLE 1.-Yields of soursop pulp and processing losses in terms of percentage of fruit processed

\begin{tabular}{|c|c|c|c|c|c|c|c|}
\hline \multirow{2}{*}{ Treatment } & \multirow{2}{*}{ Run } & \multirow{2}{*}{$\begin{array}{l}\text { Peel and } \\
\text { cores }\end{array}$} & \multirow{2}{*}{$\begin{array}{l}\text { Seeds and } \\
\text { pulper } \\
\text { waste }\end{array}$} & \multirow{2}{*}{$\begin{array}{c}\text { Waste } \\
\text { from } \\
\text { finisher }\end{array}$} & \multirow{2}{*}{$\begin{array}{c}\text { On- } \\
\text { determine } \\
\text { losses }\end{array}$} & \multicolumn{2}{|c|}{ Pulp recovery } \\
\hline & & & & & & $\begin{array}{c}\text { Unpeeled } \\
\text { fruit }\end{array}$ & $\begin{array}{l}\text { Peeled } \\
\text { fruit }\end{array}$ \\
\hline $\begin{array}{l}\text { Pulper with } 0.060 \text {-inch } \\
\text { screen, finisher with } \\
0.020 \text {-inch screen }\end{array}$ & $\begin{array}{l}1 \\
2 \\
3\end{array}$ & $\begin{array}{l}\text { Percent } \\
30.00 \\
30.80 \\
37.10\end{array}$ & $\begin{array}{l}\text { Percent } \\
12.64 \\
11.72 \\
11.72\end{array}$ & $\begin{array}{l}\text { Percent } \\
4.64 \\
1.76 \\
1.56\end{array}$ & $\begin{array}{l}\text { Percent } \\
5.96 \\
6.46 \\
4.31\end{array}$ & $\begin{array}{l}\text { Percent } \\
46.70 \\
49.21 \\
45.31\end{array}$ & $\begin{array}{l}\text { Percent } \\
66.70 \\
71.10 \\
72.00\end{array}$ \\
\hline $\begin{array}{l}\text { Pulper with } 0.045 \text {-inch } \\
\text { screen, finisher with } \\
0.020 \text {-inch screen }\end{array}$ & $\begin{array}{l}\mathbf{1} \\
\mathbf{2} \\
\mathbf{3}\end{array}$ & $\begin{array}{l}22.60 \\
24.16 \\
24.10\end{array}$ & $\begin{array}{l}13.70 \\
12.26 \\
13.23\end{array}$ & $\begin{array}{l}3.04 \\
4.64 \\
1.00\end{array}$ & $\begin{array}{l}7.04 \\
8.75 \\
7.99\end{array}$ & $\begin{array}{l}53.62 \\
50.19 \\
53.70\end{array}$ & $\begin{array}{l}70.50 \\
66.20 \\
70.70\end{array}$ \\
\hline
\end{tabular}

total solid content, total and reducing sugars, vitamin $\mathrm{C}$, and color at about 6-month intervals. For analysis, the pulps were thawed at room temperature and homogenized in a Waring Blendor.

For $\mathrm{pH}$ and total acidity measurements, approximately $10 \mathrm{~g}$. of pulp were weighed and diluted with water to $100 \mathrm{ml}$. The $\mathrm{pH}$ was measured with a glass-calomel electrode system and titratable acidity was determined by titration with $0.1 \mathrm{~N} \mathrm{NaOH}$ solution to $\mathrm{pH} 8.1$ using glass-calomel electrodes. Acidity was calculated as anhydrous citric acid percent pulp.

Soluble solids were measured with a refractometer. Total solids were determined by drying a weighed quantity of pulp in a drying dish and dried under vacuum to constant weight at $60^{\circ} \mathrm{C}$.

Total and reducing sugars were determined by the Lane and Eynon volumetric method (17). Ascorbic acid was determined by the iodate method as modified by Ballantine (2). 
Color was measured in a Hunter Tristimulus colorimeter using a white plate with $R d=59.5, a=-2.2, b=+22.4$ as standard.

Peroxidase activity was tested by the method of Joslyn (11).

For the organoleptic evaluation of the samples, the following procedure was used: All samples without sugar were diluted with 3 volumes of water, $125 \mathrm{~g}$. of sugar were added for each can of pulp used $(211 \times 304)$, which resulted in a drink with a soluble solid content of $15.0^{\circ}$ Brix. The sweetened samples were diluted with 3 volumes of water and no additional sugar was added. The samples were blended and presented to tasters under red light. Tasters were requested to rate each sample according to its overall quality in a 6-point scale ranging from "like very much" (6 points) to "dislike" (1 point). After tasting the samples for overall quality, tasters were required to indicate the levels of off-flavors in a 5-point scale where 5 points indicated "no perceptible off-flavors" and 1 point, "strong off-flavors."

For the second and third evaluation after 7 and 13 months of storage, the samples were also rated by the method of Kramer and Ditman (13) using $a+2,-2$ scale.

For the microbiological examination, the procedures outlined by the American Public Health Association were followed (23). The samples were removed from the freezer and stored overnight at $45^{\circ} \mathrm{F}$. After standing for 1 hour at room temperature, the cans were placed in a shaker for 15 minutes. The cans were opened and a sample of about $50 \mathrm{~g}$. removed with a large pipette. The sample then was transferred to a sterile blender and mixed with $450 \mathrm{ml}$. sterile distilled water for 2 minutes. Aliquot dilutions of $10^{2}$ and $10^{3}$ were plated for bacteria using Difco Culture media, tryptone glucose. The number of microorganisms were calculated per $\mathrm{g}$. of pulp.

\section{RESULTS AND DISCUSSION}

\section{PULP EXTRACTION AND PROCESSING}

Six batches of fruits ranging in weight from 128 to 345 pounds were processed during the course of this work. Three lots were processed using a 0.045-inch screen in the pulper and three lots using a 0.060-inch screen. Yields of pulp and processing losses for these six lots are given in table 1. Peeling losses calculated as peel percent fruit, including the cores, ranged from 22.6 to 37.1 with an average value for all lots processed of 31.45. Pulp recoveries calculated as pulp-percent fruit ranged from 45.3 to 53.7. The use of two screens with perforations of different size had no apparent effect on the yields of pulp. The yield of pulp obtained when using the two types of screens is given in the last column of table 1, calculated as the pulp-extracted-percent mixture of pulp and seeds fed to the pulper. 
Pulp recoveries using the paddle type pulper with four brushes followed by treatment with a finisher provided with 0.020 -inch screen were in the same range as reported by Sánchez et al. (24). These authors noted a 72-percent recovery based on pulp and seed weights, extracting the pulp by dispersing the mixture in water, separating the seeds by screening, followed by treatment of the pulp dispersion in a paddle finisher.

The pulp obtained was white, smooth, and free from fiber and dark specks. It was observed in previous experiments that some soursop pulps turned pink on standing. No such discoloration was observed in any of our recently processed pulps.

\section{EFFECT OF HEAT ON QUALITY AND SHELF LIFE OF UNSWEETENED PULP}

The effect of heat at different temperatures on quality and shelf life of the pulp was studied as follows: Eight lots of pulp were processed as indicated in table 2. The two first lots noted were controls packed without heating but run through the three Votators as other heat-treated pulps. The activity of the peroxidases in the pulp was measured and the results are shown in table 2. Complete inactivation of the peroxidases was attained at temperatures of $150^{\circ} \mathrm{F}$. or above.

The eight lots of pulp packed in these experiments were obtained from two batches of fruit processed. The chemical composition and color of the pulps are given in table 3. Each lot of pulp was analyzed after storage at $-10^{\circ} \mathrm{F}$. for 223 to 225 and 396 to 419 days, respectively. No significant change was observed in any of the constituents measured, with exception of ascorbic acid. No change occurred in color. Table 4 shows the ascorbic acid content, as well as retention of the vitamin of the pulp, from each treatment at different intervals during storage. Although heating appeared to have no appreciable effect on the ascorbic acid content of fresh pulp, it should be noted that pulp heated to $185^{\circ}$ and $200^{\circ} \mathrm{F}$. had a higher initial ascorbic acid content than the other pulps. Because these two lots were prepared from batches of pulp with an ascorbic acid content of 17.4 and $15.6 \mathrm{mg}$. per 100 g., respectively, the apparent increase in ascorbic acid probably is due to the formation of reducing substances upon heating; it is natural to expect some destruction of ascorbic acid when heating to higher temperatures.

The figures obtained for the ascorbic acid retention during storage do not show any definite trend which can be related to temperature effect. The ascorbic acid retention value exceeded 100 percent in many samples. The apparent increase in ascorbic acid content during storage has been observed previously (21). 
TABLE 2.-Effect of heat treatments on inactivation of peroxidase

\begin{tabular}{c|c|c|c|c}
\hline \multicolumn{3}{|c|}{ Temperature in } & F. after Votator & Peroxidase activity \\
\hline Lot number & Steam heated & Water cooled & Ammonia cooled & \\
\cline { 2 - 4 } 1 & 74 & 70 & 50 & + \\
2 & 77 & 72 & 50 & + \\
3 & 130 & 70 & 50 & + \\
4 & 150 & 86 & 47 & - \\
5 & 165 & 97 & 50 & - \\
6 & 175 & 91 & 50 & - \\
7 & 185 & 97 & 50 & - \\
8 & 200 & 95 & 50 & \\
\hline
\end{tabular}

TABLE 3.-Chemical composition and color of the pulp from two batches of fruit processed

\begin{tabular}{l|l|c|c}
\hline \multicolumn{1}{c|}{ Characteristic measured } & \multicolumn{1}{c|}{ Onits } & Batch 1 & Batch 2 \\
\cline { 2 - 4 } Total solids & Percent & 16.6 & 18.6 \\
Total sugars as invert & Do. & 11.6 & 12.5 \\
Reducing sugars & Do. & 9.5 & 11.7 \\
Acidity as anhydrous citric & Do. & .89 & .96 \\
$\quad$ acid & & & 17.4 \\
Soluble solids & 'Brix & 3.61 & 3.65 \\
pH & & & \\
Color & Hunter values & 39.9 & 38.8 \\
& $R_{d}$ & -2.3 & -2.0 \\
& $a$ & 11.8 & 11.9 \\
Ascorbic acid & $b$ & 15.6 & 17.4 \\
\hline
\end{tabular}

TABLE 4.-Content and percent retention of ascorbic acid in soursop pulps after different periods of storage at $-10^{\circ} \mathrm{F}$.

\begin{tabular}{|c|c|c|c|c|c|}
\hline \multirow{3}{*}{$\begin{array}{l}\text { Highest processing } \\
\text { temperature in }{ }^{\circ} \mathrm{F} \text {. }\end{array}$} & \multicolumn{5}{|c|}{$\begin{array}{l}\text { Values for the ascorbic acid content in mg./100 ml. }(C) \text { and percent retentior } \\
(R) \text { after storage at }-10^{\circ} \mathrm{F} \text {. for the period in days indicated }\end{array}$} \\
\hline & \multirow{2}{*}{$\frac{34-46}{C}$} & \multicolumn{2}{|c|}{ 223-235 } & \multicolumn{2}{|c|}{$396-419$} \\
\hline & & C & $\boldsymbol{R}$ & $C$ & $\boldsymbol{R}$ \\
\hline 74 & 17.43 & 14.28 & 84.90 & 16.44 & 94.30 \\
\hline 77 & 15.60 & 13.20 & 84.60 & 11.41 & 73.10 \\
\hline 130 & 16.25 & 16.58 & 102.00 & 15.81 & 97.20 \\
\hline 150 & 17.07 & 14.94 & 87.50 & 16.24 & 95.10 \\
\hline 165 & 15.72 & 19.16 & 121.80 & 17.21 & 109.50 \\
\hline 175 & 16.33 & 15.95 & 97.67 & 17.90 & 109.60 \\
\hline 185 & 22.78 & 20.64 & 90.60 & 19.57 & 85.90 \\
\hline 200 & 24.76 & 18.41 & 74.40 & 17.54 & 70.80 \\
\hline
\end{tabular}


The effect of heat treatments on plate count totals is shown in the following tabulation:

$\begin{array}{cr}\text { Processing temperature in }{ }^{\circ} \boldsymbol{B} . & \text { Organisms/ml. } \\ 74 & 8,150 \\ 77 & 11,766 \\ 130 & 7,450 \\ 150 & 500 \\ 165 & 1,000 \\ 175 & 0 \\ 185 & 0 \\ 200 & 0\end{array}$

Heating to $175^{\circ} \mathrm{F}$. and above resulted in destruction of bacteria. In those pulps with the higher plate counts, a marked reduction in the number of organisms per ml. resulted during storage.

As previously mentioned, the lots of pulp studied were prepared from two batches of fruit to measure the effect of the heat treatment and storage period on the organoleptic properties without introducing the effect of a possible variation in flavor because of difference in the fruit lots. Each group of pulp was appraised separately for flavor. The results of the organoleptic tests are given in table 5.

No appreciable effect of the heat treatment on the organoleptic properties was observed in the first group of samples as shown in table 5. The 6-point scale was used to rate overall quality of the sample and a 5-point scale was used to measure the intensity of off-flavors. All samples, irrespective of heat treatment given, behaved alike during storage. The samples were submitted to organoleptic appraisal at the end of the storage period by the method of Kramer and Ditman (13) using a +2, -2 scale. No significant difference was observed in quality among the four samples. The average score for the four samples ranged from 0.60 to 0.75 .

Similar results were obtained from the second set of samples. No differences were observed in sample quality or off-flavor intensity among the four samples stored at $-10^{\circ} \mathrm{F}$. for 421 days. No changes in sample quality or intensities of off-flavor were observed at the end of the storage period among the samples processed at $77^{\circ}, 150^{\circ}$, and $175^{\circ} \mathrm{F}$. The sample processed at $200^{\circ} \mathrm{F}$., however, was found to be inferior to the others. These results were verified when the samples were compared by the Kramer and Ditman method, the sample processed at $200^{\circ} \mathrm{F}$. being rejected. The results of the tests were significant at the 1-percent probability level.

\section{EFFECT OF HEAT TREATMENT ON QUALITY AND SHELF LIFE OF SWEETENED PULPS}

Soursop pulps with cane sugar added to $45^{\circ}$ and $59^{\circ}$ Brix, respectively, were processed at the temperatures indicated in table 6 . The chemical 
TABLE 5.-Organoleptic quality of frozen soursop pulps packed without sugar after different periods of storage at $-10^{\circ} \mathrm{F}$.

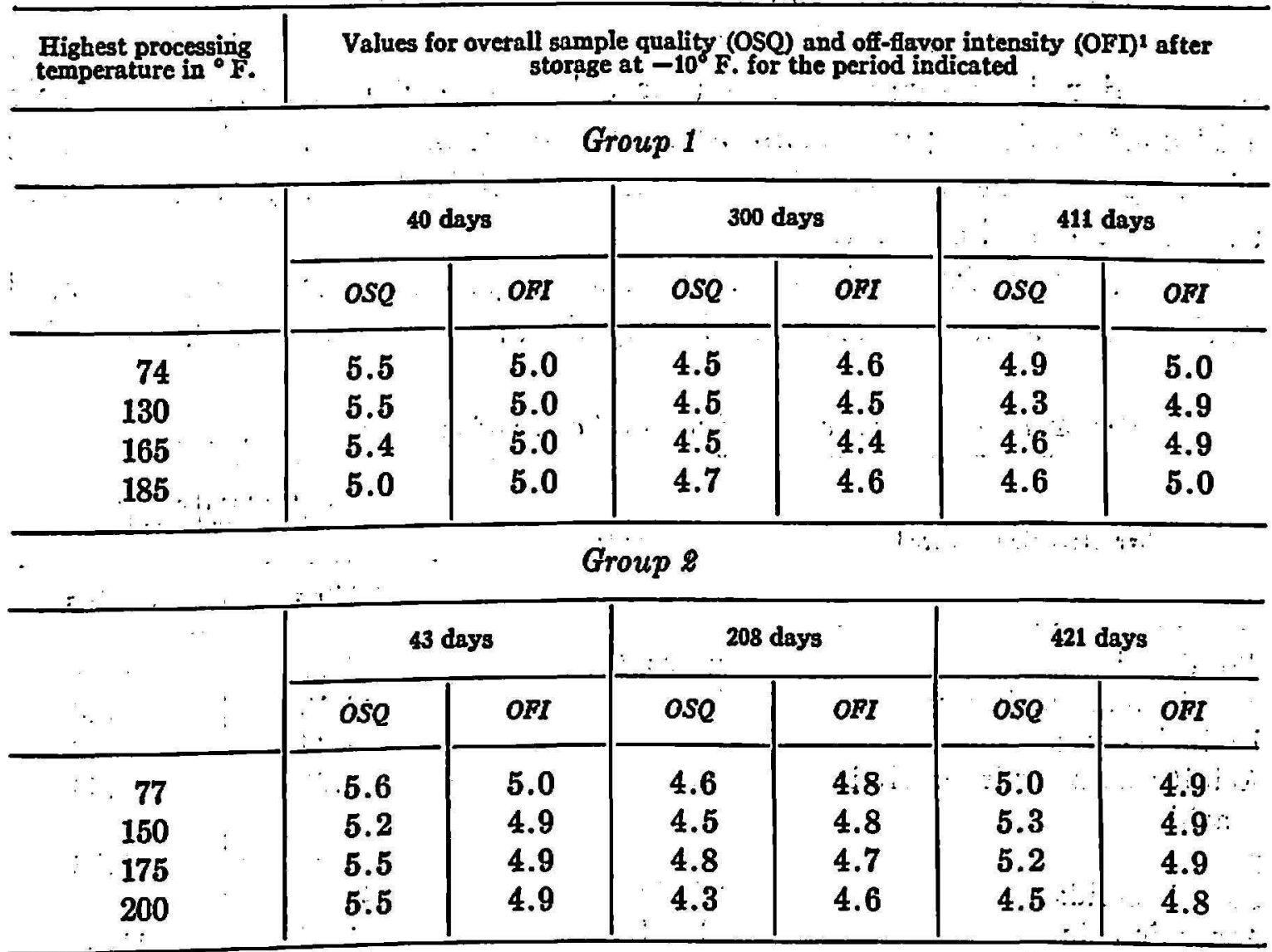

1 Overall sample quality was judged on a 6-point scale from $6=$ "like very much" to $1=$ "dislike." Off-flsvor intensity was judged on a 5-point scale from $5=$ "no perceptible off-flavor" to 1 = "strong off-flavor."

TABLE 6.-Processing temperatures for the sweetened soursop pulps

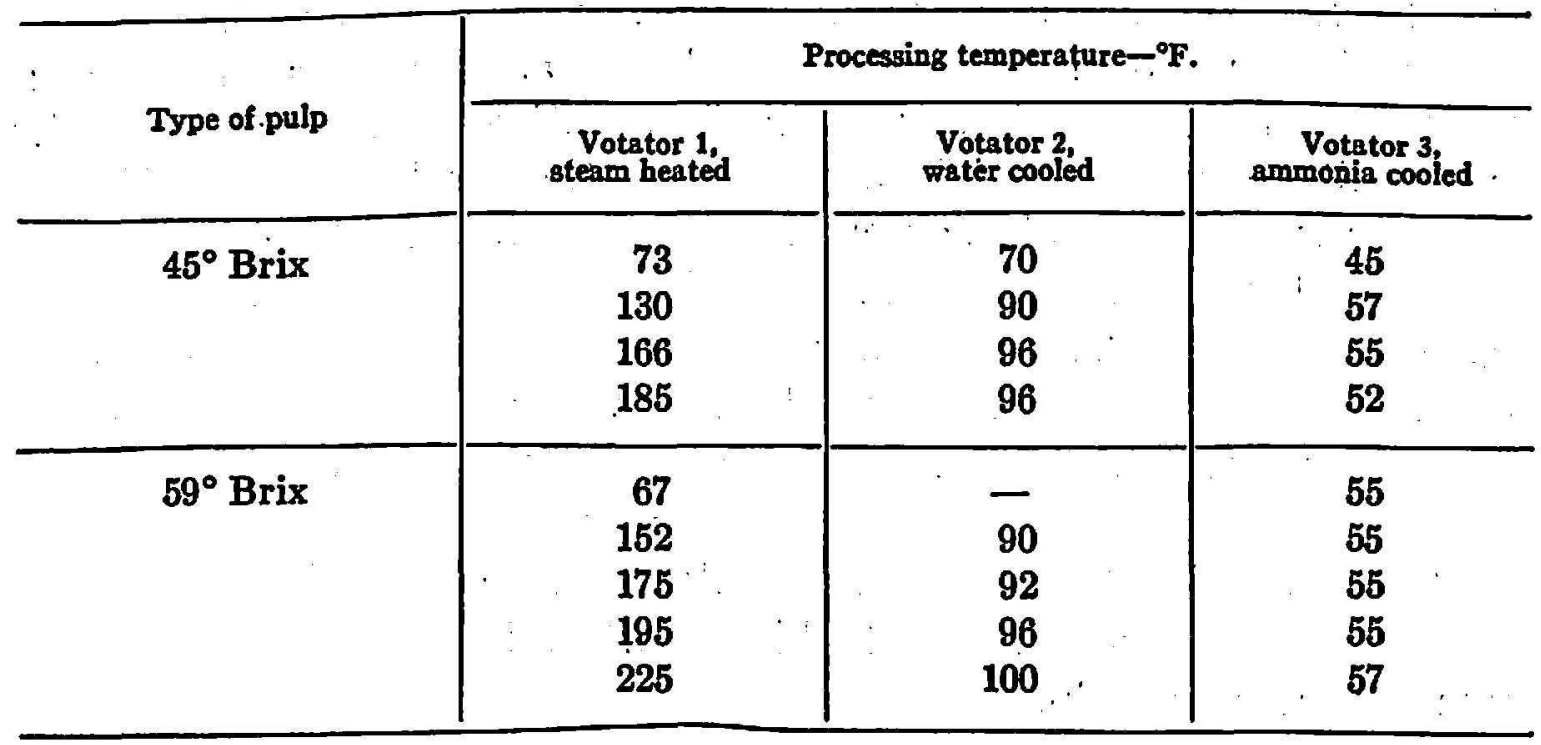


composition and color of the unheated pulps are shown in table 7. All lots were analyzed again 215 to 222 and 398 to 400 days after being packed. No changes were observed during the storage period in total acidity, $\mathrm{pH}$, total and reducing-sugar content or color. The changes in the ascorbic acid content during processing and storage are shown in table 8. Heating of the pulps irrespective of the sugar content had no apparent effect on the ascorbic acid content.

In three of the lots of the $45^{\circ}$ Brix pulp, an apparent increase was observed in the ascorbic acid content which ranged from 109.05 to 133.90. Retention

TABLs 7.-Chemical composition and color of sweetened soursop pulp

\begin{tabular}{l|l|r|r}
\hline \multicolumn{1}{c|}{ Characteristic measured } & Units & \multicolumn{2}{c}{$\begin{array}{c}\text { Values for the type } \\
\text { of pulp indicated }\end{array}$} \\
\cline { 2 - 4 } & & $45^{\circ}$ Brix & $59^{\circ}$ Brix \\
\hline Total solids & Percent & 45.75 & 58.31 \\
Total sugars as invert & Do. & 43.13 & 58.40 \\
Reducing sugars & Do. & 9.44 & 9.22 \\
Acidity as anhydrous citric & Do. & .62 & .46 \\
acid & & 3.62 & 3.76 \\
pH & & 45.30 & 59.00 \\
Soluble solids & Brix & 11.60 & 11.57 \\
Ascorbic acid & Mg./100g. & 31.5 & 33.6 \\
Color & Hunter values & -2.2 & -2.1 \\
& Rd & 12.0 & 12.5 \\
\hline
\end{tabular}

of ascorbic acid in the $59^{\circ}$ Brix pulp ranged from 75.00 to 91.68 percent, with the lower retention found in the sample processed at $225^{\circ} \mathrm{F}$.

Data from the organoleptic tests conducted after three storage periods $(25,280$, and 480 days) showed no significant difference among the samples in overall quality and off-flavor intensity. Neither heating to different temperatures nor the addition of sugars to two different levels had much effect on flavor and keeping quality. All samples were rated within the same range when the 6-point hedonic scale was used and no off-flavors could be detected even after $\mathbf{4 0 0}$ days in storage. When the samples at each sugar level were compared among themselves using a $+2,-2$ scale, no difference among the samples was observed.

Plate counts for the two groups of pulps are given in table 9. Increasing the processing temperature resulted in a marked decrease in the number of organism per g. of pulp. 
EFFECT OF THE ADDITION OF FOUR LEVELS OF ASCORBIC ACID

During the pulping and finishing operations the pulps are beaten to such an extent that appreciable quantities of air are incorporated. Such additional air may lead to oxidation. Adding ascorbic acid to reduce oxida-

TABLE 8.-Content and percent retention of ascorbic acid in sweetened soursop pulps after different periods of storage at $-10^{\circ} \mathrm{F}$.

\begin{tabular}{|c|c|c|c|c|c|c|}
\hline \multirow{2}{*}{ Type of pulp } & \multirow{2}{*}{$\begin{array}{c}\text { Highest } \\
\text { processing } \\
\text { temperature } \\
\text { in } \\
\text { F. }\end{array}$} & \multicolumn{5}{|c|}{$\begin{array}{l}\text { Values for ascorbic acid content in mg. } / 100 \mathrm{~g} \text { (C) } \\
\text { and percent retention (R) after storage at } \\
\text { for the period in days indicated }\end{array}$} \\
\hline & & 43-55 & & & & \\
\hline $45^{\circ}$ Brix & $\begin{array}{r}73 \\
130 \\
166 \\
185\end{array}$ & $\begin{array}{c}c \\
11.67 \\
13.82 \\
11.73 \\
12.53\end{array}$ & $\begin{array}{c}c \\
11.55 \\
10.78 \\
13.12 \\
13.25\end{array}$ & \begin{tabular}{r}
\multicolumn{1}{c}{$R$} \\
99.50 \\
78.00 \\
111.80 \\
105.74
\end{tabular} & $\begin{array}{c}c \\
12.65 \\
13.43 \\
15.71 \\
14.95\end{array}$ & \begin{tabular}{r}
\multicolumn{1}{c}{$\boldsymbol{R}$} \\
109.05 \\
97.18 \\
133.90 \\
119.30
\end{tabular} \\
\hline $59^{\circ}$ Brix & $\begin{array}{r}67 \\
162 \\
175 \\
195 \\
225\end{array}$ & $\begin{array}{l}11.57 \\
12.93 \\
11.67 \\
11.98 \\
11.82\end{array}$ & $\begin{array}{r}9.72 \\
10.50 \\
10.04 \\
10.30 \\
10.10\end{array}$ & $\begin{array}{l}84.01 \\
81.20 \\
86.03 \\
85.97 \\
85.40\end{array}$ & $\begin{array}{r}9.41 \\
10.30 \\
10.70 \\
9.96 \\
8.90\end{array}$ & $\begin{array}{l}81.30 \\
79.65 \\
91.68 \\
83.14 \\
75.29\end{array}$ \\
\hline
\end{tabular}

TABLE 9.-Bacteria counts of sweetened soursop pulps

\begin{tabular}{c|c|c}
\hline Type of pulp & $\begin{array}{c}\text { Highest processing } \\
\text { temperature in }\end{array}$ & Plate counts $/ 100 \mathrm{~B}$. \\
\hline $45^{\circ}$ Brix & 73 & 5600 \\
& 130 & 1500 \\
& 155 & 50 \\
& 185 & 25 \\
\hline $59^{\circ}$ Brix & 67 & 1700 \\
& 152 & 50 \\
& 175 & 40 \\
& 195 & 0 \\
& 225 & 20 \\
\hline
\end{tabular}

tion is feasible only after separation of the seeds. After pulping, four lots of pulps were enriched by the addition of $0.5,0.75,1.0$, and $1.5 \mathrm{~g}$. of ascorbic acid per pound. Immediately after the addition of the ascorbic acid, the pulps were treated in the paddle finisher, heat-processed, and canned.

The ascorbic acid content of these enriched pulps after the different processing operations are given in table 10. No loss of ascorbic acid was observed during the finishing operation. Residues from the finisher con- 
TABLE 10:-Ascorbic aicid content of enriched pulps at different processing stages

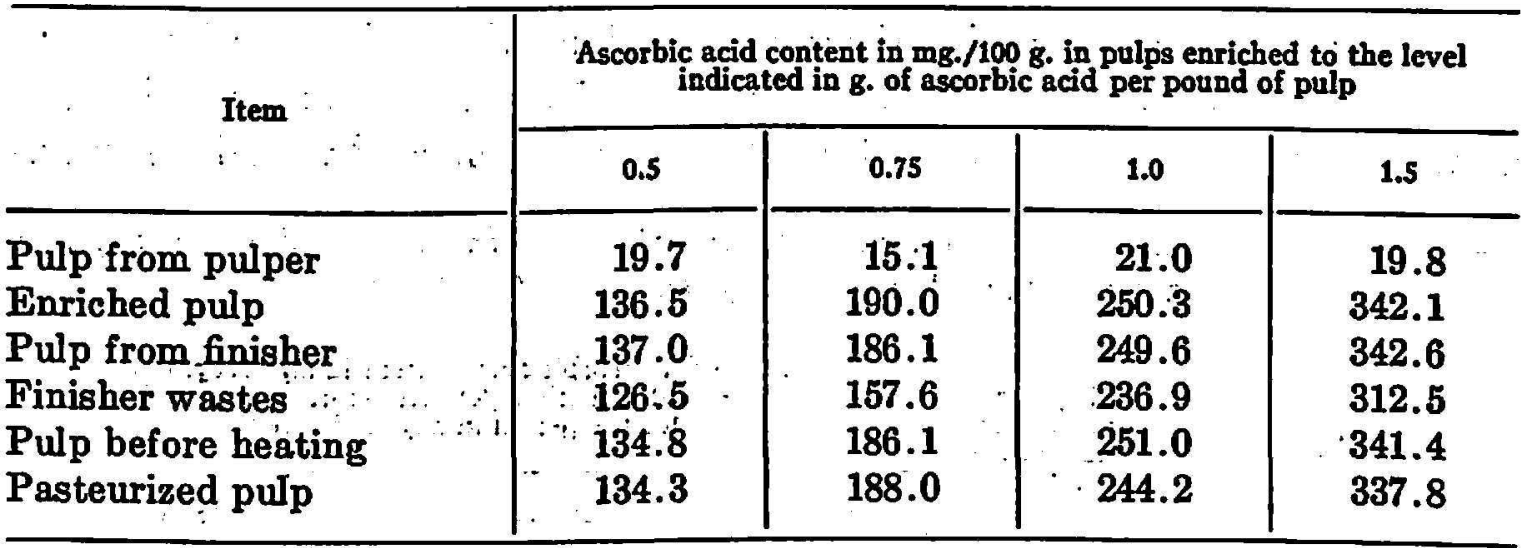

TABLE 11.-Ascorbic acid content of enriched pulps after several intervals of storage $\therefore \quad \therefore \quad$ at $-10^{\circ} \mathrm{F}$.

\begin{tabular}{|c|c|c|c|c|c|c|}
\hline \multirow{2}{*}{\multicolumn{3}{|c|}{$\begin{array}{c}\text { Level of } \\
\text { errichment in g. } \\
\text { ascorbic acid per pound }\end{array}$}} & & \multicolumn{3}{|c|}{$\begin{array}{l}\text { Mg. ascorbic acid per } 100 \mathrm{~g} \text {. of pulp at the end } \\
\text { of storage period in days indicated }\end{array}$} \\
\hline & & & & 26 to 41 & 202 to 217 & 388 to 413 : \\
\hline $\begin{array}{l}\because \\
\therefore \therefore\end{array}$ & $\begin{array}{l}0.50 \\
.75 \\
1.00 \\
1.50\end{array}$ & $\therefore$ & $\therefore$ & $\begin{array}{l}128.1 \\
185.7 \\
234.8 \\
341.3\end{array}$ & $\begin{array}{l}- \\
175.7 \\
226.5 \\
339.1\end{array}$ & $\begin{array}{l}120.6 \\
190.4 \\
240.9 \\
347.8\end{array}$ \\
\hline
\end{tabular}

TABLE 12,-Organoleptic ratings of soursop pulps pasteurized at $175^{\circ}$. F. when freshly packed and at the end of the storage period at $-10^{\circ} \mathrm{F}$.

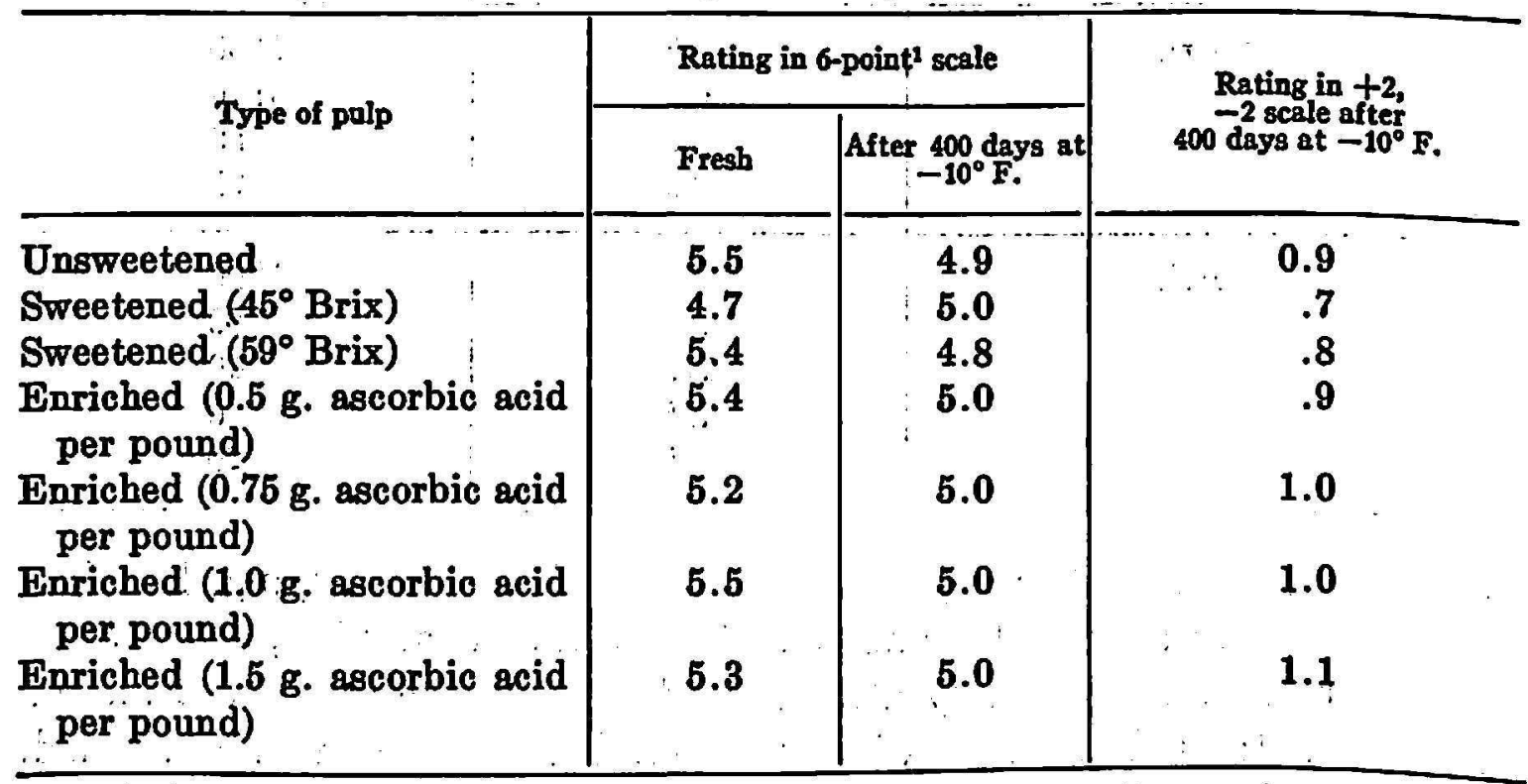

1 Two scales were used for judging sample quality, a 6-point scale ranging from $6=$ "like very. much" to $1 .=$ "dislike".' and Kramer \& Ditman $\pm 2=$ scale ranging from $+2=$ "very acceptable" to $-2=$ "unacceptable." 
tained ascorbic acid in levels approximating those of enriched pulps.' Because 100 pounds of fruit processed results only in about 3 pounds of finisher pomace; net loss of ascorbic acid by carry over in finisher wastes would not exceed 5 percent of the added quantity. The loss during pasteurization also was negligible.

The ascorbic acid content of the pulps after different periods of storage at $-10^{\circ} \mathrm{F}$. are given in table 11 . The percent retention of ascorbic acid after 388 to 413 days storage are shown in the following tabulation:

Level of enrichment (g. ascorbic acid/pound)

0.5

.75

1.00

1.5
Percent retention value

94.1

104.6

102.6

101.9

Enriched pulp behaved in a way similar to unriched, showing an apparent increase in ascorbic acid content during storage.

The results from the organoleptic tests after three storage periods (26 to $41,280,412$ to 427 days) showed that all enriched pulps retained their flavor very well throughout the storage period and were rated as good as fresh when appraised after $\mathbf{4 0 0}$ days in storage.

\section{DISCUSSION}

Three factors were studied which may have an effect on flavor, ascorbic acid retention, and shelf life of frozen soursop; namely, processing temperature, sugar content, and addition of ascorbic acid. Heating pulps to temperatures ranging from $130^{\circ}$ to around $200^{\circ} \mathrm{F}$, without sugar or with sugar added to $45^{\circ}$ and $59^{\circ}$ Brix had no effect on flavor or ascorbic acid retention during storage. Hohl et al. ( $(9)$ reported blanched peach purees retained ascorbic acid better than unblanched. Best results were obtained when the fruit was heated long enough to inactivate the enzymes. In the case of soursop pulp, inactivation of the peroxidases had no effect on retention of ascorbic acid or on flavor or color during storage. When unsweetened pulps were heated, the peroxidases were inactivated at $150^{\circ} \mathrm{F}$. When sugar was added to $45^{\circ}$ Brix the peroxidases were inactivated at $185^{\circ} \mathrm{F}$. No differences in any of the characteristics measured were observed among the pulps with or without the enzyme system inactivated. The only beneficial effect of the heating treatment was to reduce organism plate counts. Heating all pulps to $175^{\circ} \mathrm{F}$. or above lowered the plate counts to very low levels.

It has been claimed (12,21) that addition of sugar greatly improves keeping quality of frozen fruit juices and purees. No such effect has been observed with soursop pulp. Our data indicates that the quality of a drink 
prepared with unsweetened pulps was as good as that prepared from sweetened. No effect on the retention of ascorbic acid was observed. The good flavor and stability of sweetened pulps suggest that a product of excellent quality for direct consumer use can be prepared by the addition of sugar to $45^{\circ}$ or $60^{\circ}$ Brix. For use, the product need only to be diluted with 3 volumes of water as in the case of concentrated, frozen orange juice. Such a soursop product has a most pleasing flavor which should find a ready market, especially in tropical countries where people already are familiar with and like the exotic flavor. The unsweetened pulp likewise can be preserved by freezing for manufacture of ice creams, nectars, and syrups without further treatment.

Ascorbic acid has been used for a long time as an antioxidant in frozen fruit and vegetable products. No such clear cut effect was observed by the addition of four levels of ascorbic acid to soursop pulp as shown in table 12. Additional ascorbic acid had little effect on flavor improvement. This may be due to the fact that the ascorbic acid was added after pulping when air already had been incorporated into a stable pulp.

In all samples studied, whether enriched or not, the ascorbic acid retention was very high after more than 400 days of storage at $-10^{\circ} \mathrm{F}$. The high retention of ascorbic acid probably is the result of maintaining the pulps at a constant temperature throughout the storage period. It has been reported $(10,8)$ that changes in ascorbic acid in frozen products during storage is dependent on storage temperature and on variations of temperature during storage. As previously indicated, the ascorbic acid retention value in many samples exceeded 100 percent. The only pulps in which a definite trend for loss of ascorbic acid was observed during storage were those sweetened to $59^{\circ}$ Brix.

Joslyn et al. (12) reported the desirability of deaerating fruit purees as a means of reducing changes in color and flavor due to oxidation. Since air is dissolved in the pulp during pulping and finishing, deaeration might be desirable. However, the excellent keeping quality of the pulps processed in these studies, which were packed without deaeration, suggest that such a treatment may not be necessary with soursop pulps.

\section{SUMMARY}

The effect of the processing temperature, of the addition of sugar to $45^{\circ}$ and $59^{\circ}$ Brix and of the addition of four levels of ascorbic acid, $0.5,0.75$, 1.0 , and $1.5 \mathrm{~g}$. per pound, on the quality, shelf-life, and ascorbic acid retention of frozen soursop pulp was investigated.

When unsweetened soursop pulps were processed at temperatures ranging from $74^{\circ}$ to $200^{\circ} \mathrm{F}$, no appreciable change in organoleptic properties were observed during a period of storage at $-10^{\circ} \mathrm{F}$. for over 400 days, in 
the pulps heated below $200^{\circ} \mathrm{F}$. The pulp heated to $200^{\circ} \mathrm{F}$. was found inferior to the others. No change in chemical composition or color was observed. The data for the ascorbic acid retention during storage do not show any definite trend which could be related to a temperature effect. Ascorbic acid retention varied from 70.8 to 94.3 percent.

Pulps with cane sugar added to $45^{\circ}$ to $59^{\circ}$ Brix, respectively, and heated to temperatures ranging from $72^{\circ}$ to $225^{\circ} \mathrm{F}$. behaved like the unsweetened pulps when stored at $-10^{\circ} \mathrm{F}$. for about 400 days. No change in total acidity, $\mathrm{pH}$, total and reducing-sugar content, or color was observed during the storage period. In the samples sweetened to $45^{\circ} \mathrm{Brix}$, ascorbic retention values ranged from 98.18 to 133.9 percent. The retention of ascorbic acid in the $59^{\circ}$ Brix pulps ranged from $\mathbf{7 5 . 0}$ to 91.7 percent, with the lower retention found in the sample processed at $225^{\circ} \mathrm{F}$. Neither heating to different temperatures nor the addition of two levels of sugar were found to affect the shelf-life.

Pulps processed at $175^{\circ} \mathrm{F}$. and enriched by the addition of $0.5, .0 .75$, 1.0 , and $1.5 \mathrm{~g}$. of ascorbic acid per pound retained their flavor very well during the storage period showing less change in the organoleptic rating than the unriched sweetened and unsweetened pulps. The level of ascorbic acid had no effect on shelf-life or sample quality. Ascorbic acid retention ranged from 94.1 to 104.6 percent. No change in other chemical constituents or color were observed during the period of observation.

Heating of the pulps reduced the plate counts of microorganisms. When the pulps were heated to about $175^{\circ} \mathrm{F}$., almost sterile packs were obtained. Peroxidases were inactivated at $150^{\circ} \mathrm{F}$. in the unsweetened pulps and at $185^{\circ} \mathrm{F}$. in the sweetened.

The results of this work indicate that two types of products can be prepared from soursop pulp: 1, A frozen pulp without sugar added, to be used for the manufacture of nectars, drinks, ice creams, and other similar products; and 2, a nectar base for direct consumer use prepared by the addition of sugar to $45^{\circ}$ or $59^{\circ}$ Brix which can be reconstituted for serving by the addition of 3 volumes of water. The addition of ascorbic acid to the nectar base would improve the shelf-life and the resulting product would have a vitamin $\mathrm{C}$ content higher than that contained in orange juice.

\section{RESUMEN}

Se estudió el efecto de los siguientes factores sobre la calidad, duración en almacén y pérdida del ácido ascórbico en pulpas de guanábana congeladas y almacenadas a $-10^{\circ} \mathrm{F} .:$ gradode temperatura durante el proceso de elaboración y adición de dos niveles de azúcar y cuatro de ácido ascórbico.

Para extraer la pulpa, se removió la cáscara a mano y se separó el corazón de la pulpa. La mezcla de pulpa y semillas se colocó en una despulpadora 
con cuatro cepillos de fibra, usando un cedazo con perforaciones do 0.060 y 0.045 pulgadas. La pulpa: sin la semilla se colocó en una refinadora de paletas con un cedazo con perforaciones de $\mathbf{0 . 0 2 0}$ pulgadas, para remover la fibra y otras impurezas. Se obtuvo un rendimiento de pulpa que fluctuó entre 45 y 53.7 por ciento del peso de la fruta procesada.

La pulpa se calent6,-a distintas temperaturas en un calentador de tipo Votator, modelo de:laboratorio. Después de este tratamiento, la pulpa se enfrib en un segundo Votator enfriado con agua y luego, para envasarla, se enfrió a una temperatura de alrededor de $50^{\circ} \mathrm{F}$. en un tercer Votator enfriado con amoníaco. Toda la pulpa se envasó en latas estañadas, y se congeló a una temperatura de $-40^{\circ} \mathrm{F}$., almacenándose luego a una temperatura de $-10^{\circ} \mathrm{F}$.

Lạs pulpas sịn azúcar, calentadas a distintas temperaturas que fluctuaron entre $74^{\circ}$ y $200^{\circ} \mathrm{F}$, se almacenaron a $-10^{\circ} \mathrm{F}$. por un periodo mayor de 400 días sin sufrir cambios aparentes en el $\mathrm{pH}$ y la acidez, en el contenido de azúcares totales y reductores, y en el color. No se observó cambio alguno en .las: propiedades organolépticas de las pulpas, excepto an aquéllas que se calentaron a $200^{\circ} \mathrm{F}$., las cuales fueron inferiores a las calentadas a temperaturas más bajas. La retención del ácido ascórbico durante el almacenamiento fluctuó entre un 70.8 y un 109.0 por ciento, sin que se encontrase relación aparente entre el tratamiento con calor y la retención de la vitamina. Los valores para el porcentaje de retención de la vitamina. Los valores para el porcentaje de retención del ácido ascórbico en exceso de 100.0 se atribuyen a la formación de substancias reductoras que interfieren en el análisis.del ácido ascórbico.

Las pulpas que se prepararon añadiéndoseles azúcar hasta alcanzar $45^{\circ}$ y $59^{\circ}$ Brix y que se calentaron a temperaturas que fluctuaron entre $73^{\circ}$ y $225^{\circ} \mathrm{F}$. se comportaron durante el almacenamiento de modo similar a las que se prepararon sin azúcar. No se observó cambio alguno en la acidez total ni en el pH, así como tampoco en el contenido de azúcares reductores y totales, ni en el color. El valor de retención del ácido ascórbico durante el almacenamiento fluctuó entre un 98.0 y un 133.9 por ciento en la pulpa a $45^{\circ}$ Brix . En la pulpa a $59^{\circ}$ Brix, la retención del ácido ascórbico fluctuó entre un 75.3 y un 91.7 por ciento, observándose la mayor pérdida de ácido ascórbico en las muestras calentada as $225^{\circ} \mathrm{F}$. Todas las pulpas se conservaron muy bien durante el periodo que duró el estudio, sin cambios aparentes en el sabor y en otras propiedades organolépticas. Los diversos tratamientos con calor y los dos niveles de azúcar que se usaron no afectaron la calidad de las pulpas ni su duración en almacén.

Para estudiar el efecto que tiene el enriquecimiento de la pulpa con distintos niveles de ácido ascórbico sobre su calidad y su conservación cuando se almacenan a una temperatura de $-10^{\circ} \mathrm{F}$, a cuatro de los lotes 
de pulpa se les añadió ácido ascórbico én cantidades que fluctuaron entré 0.5 y $1.5 \mathrm{~g}$. por libra. El ácido se le añadió a la pulpa inmediatamente después de despulparse y antes de colocarse en la refinadora. Se calentaron las pulpas a $175^{\circ} \mathrm{F}$. y se envasaron en latas estañadas, congelándose y almacenándoseles luego, según se describió anteriormente. Estas pulpas se mantuvieron en muy buenas condiciones por un periodo de almacenamiento de más de 400 días. Las pulpas enriquecidás con ácido ascórbico sufrieron menos cambios en el sabor que las que no se enriquecieron y envasaron con y sin azúcar. El valor de a retención del ácido ascórbico durante el periodo de almacenamiento fluctuó entre un 94.1 y un 104.6 por ciento.

En todas las pulpas que se estudiaron, el aumento en la temperatura redujo considerablemente el contaje de microorganismos, obteniéndose pulpas casi esteriles al alcanzar una temperatura de $175^{\circ} \mathrm{F}$.

Los resultados que se han obtenido de este trabajo tienden a indicar que de la pulpa de guanábana pueden prepararse dos.productos congeládos: La pulpa puede congelarse sin azúcar para ser usada en la elaboración de néctares, refrescos, siropes, helados y otros productos similares. Se puede elaborar también un producto para uso directo del consumidor, añadiéndosele azúcar a $45^{\circ}$ o a $59^{\circ}$ Brix. Al diluir este producto con 3 volúmenes de agua se obtiene un néctar o refresco de excelente calidad. Para aumentar. su valor nutrimental puede añadirse le ácido áscórbico, siendo así posible obtener un producto con un contenido de ácido ascórbico mayor que el del jugo de china.

\section{LITERATURE CITED}

1. Adriano, F. T. A., Valenzuela, A., Miranda, L. G., Studies on the quick freezing of Philippine fruits and utilization of the frozen pack products, Philippine $J$. Agr. 4 (1): 41-59, 1933.

2. Ballantine, R., Determination of ascorbic acid in citrus fruit juices, Ind. Eng. Chem. Anal. Ed. 13 (2): 89-90, 1941.

3. Boyle, F. P., How to freeze guavas as spread puree, Quick Frozen Foods 20: 101-3, 1958.

4. Boyle, F. P., Seagrave Smith, H., Sakata, S., Sherman, D. G., Commercial guava processing in Hawaii, Bull. 111, Hawaii Agr. Exp. Sta. 17-24, 1957.

5. Cruess, W. V., Hohl, L. A., Jiménez, M. A., Nichols Roy, S., Torres, R., Zorrilla, M., Experiments with guavas, Fruit Products J. 24: 263-66, 283, 285, 1945.

6. DuBois, C. W., Ascorbic acid and color in food products, Food Tech. s: 119-21, 1949.

7. Franco Betancourt, J., Alvarez Guerrero, J., Serie Estudios Sobre Trabajos de Investigación, Instituto Cubano de Investigaciones Agrícolas, Bol. 11, 29-38, 1960.

8. Guadagni, D. G., Nimmo, C. C., and Jansen, E. F., The time temperature tolerance of frozen foods. II. Retail packages of frozen peaches, Food Tech. 11: $33-42,1957$.

9. Hohl, L. A., Buck, P., Rosoff, H., Further studies of frozen fruit and vegetable purees, Food Tech. s: 100-10, 1949. 
10. Huggart, R. L., Harman, D. A., Moore, J., Ascorbic acid retention in frozen concentrated citrus juices, $J$. Am. Dietetic Assoc. 80: 682-4, 1954.

11. Joslyn, M. A., Enzyme activity in frozen vegetable tissue Advances in Enzymology, Interscience Publishers Co., Inc., New York, N. Y., 9: 647-8, 1949.

12. Joslyn, M. A., and Hohl, L. A., The commercial freezing of fruit products, Bull. 703, Calif. Agr. Exp. Sta., 83-7, 1948.

13. Kramer, A., and Ditman, L. P., A simplified variable taste panel method for detecting flavor changes in vegetables treated with pesticides, Food Tech. 10: 155-59, 1956.

14. Latimer, R. A., New techniques by Borden yield flavor rich puree, Food Ind. 17: 1038-39, 1945.

15. Lynch, L. J., Tom Chang, A., Lum, J. C., Sherman, D. G., Seale, P. E., Hawaii Food Processors Handbook, Circ. 55, Hawaii Agr. Exp. Sta. 12, 1959.

16. Mathur, P. B., Kirpol Singh, K., Srivastava, H. C., Frozen storage of some fruit products, Food Sci. (Mysore) 7: 281-3, 1958.

17. Official Methods of Analysis of the Association of Official Agricultural Chemists, 9th. ed., Washington, D.C., p. 426, 1960.

18. Mustard, M. and Stahl, A. L., The freezing of tropical and subtropical fruits, Quick Frozen Foods 12 (7): 136-8, 1950.

19. - The freezing preservation of some tropical and subtropical fruits, Fla. State Hort. Soc. Proc. 61: 275-79, 1948.

20. Orr, K. J., Loss of vitamin $C$ in frozen guava puree and juice, Progress Notes 98, Hawaii Agr. Exp. Sta., 1-7, 1954.

21. Paul, P., Preparation of fruit purees, Fruit Products J. 28: 196-7, 221, 1949.

22. Rahman, A. R., Anziani, J., Cruz Cay, J. R., Factors affecting the stability of vitamin $C$ in tropical fruit juices and nectars, J. Agr. Univ. P.R. 48: 1-12, 1964.

23. Recommended Methods for Microbial Examination of Foods, American Public Health Association, 2nd. ed., 91, New York, N.Y., 205 pp., 1966.

24. Sánchez Nieva, F., Igaravidez, L., L6pez Ramos, B., The preparation of soursop nectar, Tech. Paper 11, Univ. P.R., Agr. Exp. Sta., 19 pp., 1953.

25. Scott, F. S., Jr., An economic analysis of the market for frozen guava nectar base, Agr. Econ. Bull. 14, Hawaii Agr. Exp. Sta., 21 pp., 1958.

26. Strachan, C. C. and Moyls, A. W., Ascorbic acid, citric and dehydroxymalic acids and antioxidants in frozen foods, Food Tech. 8: 327-32, 1949.

27. Tressler, D. K., Evers, C. F., The Freezing Preservation of Foods, vol. 1, pp. 59-94, The Avi Publishing Co., Inc., Westport, Conn., 1957.

28. Wright, C. E., Commercial promise seen for eleven new guava products, Food Eng. 84: 141, 161, 1952. 